\title{
Claiming Authority: Negotiating Challenges for Women Leaders
}

\section{Citation}

Bowles, Hannah R., and Kathleen L. McGinn. 2004. "Claiming Authority: Negotiating Challenges for Women Leaders." In The Psychology of Leadership: New Perspectives and Approaches, edited by D. Messick and R. Kramer, 191-208. Mahwah, NJ: Lawrence Erlbaum Associates.

\section{Permanent link}

http://nrs.harvard.edu/urn-3:HUL.InstRepos:38984199

\section{Terms of Use}

This article was downloaded from Harvard University's DASH repository, and is made available under the terms and conditions applicable to Open Access Policy Articles, as set forth at http:// nrs.harvard.edu/urn-3:HUL.InstRepos:dash.current.terms-of-use\#OAP

\section{Share Your Story}

The Harvard community has made this article openly available.

Please share how this access benefits you. Submit a story.

Accessibility 


\title{
Claiming Authority: Negotiating Challenges for Women Leaders
}

\author{
Hannah R. Bowles \\ Kennedy School of Government \\ Harvard University \\ and \\ Kathleen L. McGinn \\ Graduate School of Business Administration \\ Harvard University
}

Style isn't women's problem. The most recent research on gender in leadership indicates that while women tend to adopt different leadership styles than men, they are rated to be just as—if not more-effective on important leadership dimensions. Meta-analytic research shows that women tend to be relatively more democratic (as opposed to autocratic) leaders than are their male peers (Eagly \& Johnson, 1990). These statistical effects are enlivened by the testimonies of accomplished women who celebrate the development of what they claim is a distinctive voice for women leaders (Rosener, 1990). In a style that fits comfortably for them, women leaders have donned agilely the traditionally male leadership mantle. The popular press cheers that "women rule" as leaders (Sharpe, 2000), and the most recent meta-analytic research on gender and leadership supports their claim (Eagly, Johannesen-Schmidt, \& van Engen, 2002, p. 36).

So, why —if both men and women have what it takes to be effective leaders—are women lagging so far behind men in the race to the top? We propose that the gender gap in leadership is not about leading per se, but rather about claiming positions of authority. Where the most significant gender differences in relation to leadership occur is in the claiming of authority—men 
claim and hold a greater number of leadership positions than do women-not in what men and women do once they achieve that authority.

In this chapter, we explore four dominant explanations for the gender gap in claiming authority: gender bias, lack of experience, lack of motivation, and familial responsibility. There is validity to each of these explanations, but there are limitations as well. Each explanation suggests both barriers and opportunities. We argue that each potential barrier is surmountable through capitalizing on opportunities for negotiation. Drawing on recent developments in research on gender in negotiation, we propose an explanation for why the types of negotiations involved in claiming positions of authority are precisely those types of negotiations in which gender differences favoring males tend to emerge. We suggest future research to further explore the barriers and opportunities encountered by women negotiating to claim authority.

\section{Dominant Explanations for the Gender Gap in Leadership}

Four explanations for why women are underrepresented in positions of leadership emerge out of the gender and work literature. Each suggests barriers and opportunities for women attempting to claim authority. One leading explanation is that gender bias in the workplace poses normative constraints on women advancing to higher levels of authority (Eagly \& Karau, 2002). Another explanation is that women lack the specific types of experience and skills to be serious contenders for the top job (Catalyst, 1998; Wirth, 2001). In spite of the fact that nearly half of all managers are women, only a small minority of senior women managers carry the types of profit-and-loss or revenue-generating responsibilities that lead to the very top (Wirth, 2001, p. 39). A third explanation is that women do not seem as interested as men in gaining the necessary experience and taking the initiative to lead (Wellington \& Giscombe, 2001). Finally, and related to the question of whether women really want to lead, is the issue of women assuming primary 
responsibility for household and family and being less able or willing than men to balance personal life demands with the demands of top leadership positions.

\section{$\underline{\text { Gender Bias }}$}

\section{Barriers to Claiming Authority}

Occupational positions dominated by one sex tend to be imbued with gender-consistent attributes for success (Cejka \& Eagly, 1999; Eagly \& Steffen, 2000), and the overwhelming majority of top leadership positions in American society are held by men. In 2002, less than 16 percent of the corporate officers in America’s 500 largest companies were women. While 60 of the largest 500 companies had filled at least 25 percent of their corporate officers ranks with women, 71 of the 500 did not have one women corporate officer (Catalyst, 2002). Looking to the public sector, there were only six US states with women governors in 2003, and half of the states had no woman representatives in the $108^{\text {th }}$ US Congress (Center for American Women and Politics, 2002). We are accustomed to seeing and, therefore, tend to expect to see men in charge. Women’s prospects for leadership may be obstructed by sex-typed images of leadership (Schein, 2001; Valian, 1999). We anticipate that men will assume leadership in mixed-sex groups and tend to work together and interact socially in ways that reinforce those gender-based social roles (Dovidio, Ellyson, Keating, \& Heltman, 1988; Wood \& Karten, 1986). As the ratio of women to men decreases_as is generally the case as one rises through organizational ranksresistance to women’s claiming of authority increases (Heilman, 1995; Heilman, 1980; R. M. Kanter, 1977). Women who defy the social rules of the situation and attempt to assert their authority in the absence of external validation are likely to meet with social disapproval from their counterparts (Ridgeway, 2001; Ridgeway \& Smith-Lovin, 1999; Rudman \& Glick, 1999; Valian, 1999). 
Once women manage to establish themselves in positions of authority, gender-based social roles inform how others - and the women themselves - think they should behave (Eagly, 1987; Eagly \& Johannesen-Schmidt, 2001). Gender differences (favoring males) in the evaluation of leaders are most significant when leaders take on stereotypically masculine roles (Eagly, Makhijani, \& Klonsky, 1992). Women who adopt stereotypically masculine behaviors violate the norms of female niceness, and are negatively socially sanctioned for it (Branson, 2002; Rudman \& Glick, 1999). It is no wonder, perhaps, that men and women have tended to adopt distinct leadership styles (Eagly \& Johannesen-Schmidt, 2001; Eagly \& Johnson, 1990). Opportunities for Claiming Authority

In the course of adapting to new social roles as leaders in private organizations and public institutions, women, in general, appear to have developed particularly effective leadership styles. In her most recent meta-analytic study of gender and leadership, Alice Eagly and her colleagues tested whether gender differences in leadership style would map onto measures of Burns’ (1978) theory of "transformational” and "transactional” leaders (Eagly et al., 2002). Eagly and her colleagues suspected that women might rely more heavily than men on "transformational" leadership styles and positive reward aspects of “transactional” leadership, because these behaviors would pose less of a gender role conflict than would other more control-oriented or coercive leadership styles. According to Burns, transactional leaders motivate followers by appealing to their existing preferences by coercion or reward, including contingent rewards based on performance. Transformational leaders, in contrast, “engage with others in such a way that leaders and followers raise one another to higher levels of motivation and morality” (Burns, 1978, p. 20). Recent meta-analytic research has established a significant positive correlation between leadership effectiveness and indicators of transformational leadership and the contingent 
reward dimensions of transactional leadership (Eagly et al., 2002; Lowe, Kroeck, \& Sivasubramaniam, 1996).

Even if gender biases create constraints in the style of leadership women adopt, many studies provide evidence that women’s leadership styles are just as, if not more, effective than those of their male peers. In a meta-analysis of 45 studies, Eagly and colleagues found that women were rated significantly higher than men on nearly all of the indicators of transformational leadership, as well as the contingent reward dimension of transactional leadership (Eagly et al., 2002). There were no significant gender differences observed in leaders' ability to inspire pride and respect. Furthermore, other research by Eagly and colleagues has demonstrated that gender roles are malleable, bending—albeit slowly—with changes in social conventions and the division of labor within society (Diekman \& Eagly, 2000; Wood \& Eagly, 2002). By taking on and succeeding in leadership roles in ever-greater numbers, women have the ability to erode stereotype-based assumptions that leadership is a man's job.

\section{Lack of Experience}

\section{Barriers to Claiming Authority}

One of the oft-cited barriers to women's advancement into senior management positions is a lack of critical management experiences. Although women in the US hold 47 percent of executive and managerial positions, they tend to be concentrated in the "velvet ghetto" of human resource management, education and accounting (Bureau of Labor Statistics, 2002; Wirth, 2001; Woodall, Edwards, \& Welchman, 1995). The route to the highest echelons of corporate America tends to not to flow through these "non-strategic" departments but rather through line management positions that carry relatively more revenue-generating responsibilities and higherprofile influence within the corporation. In 1999, women in the US held just over 6 percent of 
the corporate line jobs and, correspondingly, about 5 percent of the highest ranking corporate positions (e.g., chairperson, CEO, president, etc.) (Wirth, 2001, p. 39).

Opportunities for Claiming Authority

When Catalyst asked CEOs what they thought would be the most effective corporate strategies for advancing women to senior management positions, 74 percent responded "giving women high visibility assignments” (Catalyst, 1996, p. 32). Many CEOs underscore the importance of women taking the initiative in letting their managers know they are interested in career-enhancing opportunities and point out that the organizational pipeline is stacked with women poised to rise to the highest ranks (Wellington \& Giscombe, 2001). With broad-based recognition of the types of management experience that women need to obtain and a deep pool of prospective women competitors for those slots, the time should be ripe for women to fill those higher-visibility, strategic management positions in ever greater numbers.

\section{Lack of Motivation}

\section{Barriers to Claiming Authority}

Another broadly espoused explanation for why there are not more women in leadership positions is that women are not hungry for leadership positions; opportunities abound, but women do not aggressively pursue them. Research supports the notion that many women shy away from promoting themselves for leadership positions. Qualitative studies suggest that women often take on informal as opposed to official leadership roles, tending to team cohesion and group conflict behind the scenes (Fletcher, 2001; Kolb, 1992; Neubert, 1999). Other reserach suggests that women may actually avoid the term "leader," in favor of less self-serving titles such as “facilitator," “organizer,” or “coordinator” (Andrews, 1992). Consistent with the propositions of the qualitative researchers, meta-analytic research from lab and field studies on 
the emergence of leaders in initially leaderless groups has shown men to be significantly more likely than women to emerge as work group leaders, while women are more likely than men to be recognized as social facilitators (Eagly \& Karau, 1991).

As discussed in the sections on gender biases, social incentives motivate women to downplay rather than explicitly promote their desires for and competence in positions of authority. Work by Laura Rudman on the dilemmas of self-promotion shows that if a man and a women self-promote in a job situation, both communicate their competence successfully but the woman comes off as socially incompetent and undesirable for the position (Rudman, 1998). Even if a woman desires to run the show, she may be inhibited from asserting her authority by her own socialization and the expectations of others (Ridgeway, 2001).

\section{Opportunities for Claiming Authority}

However pervasive the effects of gender-based social roles and expectations may be on the motivation to claim authority, these effects are moderated by situational factors. Research by Eagly and colleagues, for instance, shows that women are more likely to emerge as leaders the longer the group interacts together and the more complex the level of social interaction becomes (Eagly \& Karau, 1991). Numerous studies have shown that the gender distribution within occupations also moderates the extent to which gender influences workplace behavior, expectations and opportunities (Cohen, Broschak, \& Haveman, 1998; Ely, 1994, 1995; Heilman, 1995; Heilman, 1980; R. Kanter, 1977; Lee, 2001). Gender is more likely to influence leadership emergence if there is a highly asymmetric sex distribution in leadership positions; in most large organizational settings, this is a structural condition likely to favor male over female leadership candidates. 
An intuitive and/or experience-based awareness of these situational constraints may explain why so many ambitious women are leaving large organizations to start their own ventures (Wirth, 2001). From the mid-eighties to the mid-nineties, the number of women-owned businesses increased by 78 percent, with survival rates exceeding the national average. While the largest share (estimated 52 percent) of women-owned businesses have been in the service sector, the top growth industries for women-owned businesses between 1987-1996 were in traditionally male sectors such as construction, wholesale trade, transportation, agribusiness and manufacturing. Between 1987-1996, women-owned business with 100 or more workers increased employment by 158 percent, which was more than double the rate for all US firms of similar size. Employment growth in women-owned businesses beat the national average in nearly every major industry and US region (Small Business Administration, 2001). It is hard to argue that women do not have the drive to lead. Women entrepreneurs have gone out and shaped organizations in ways that allow them to flourish and lead effectively. What we need now is research investigating and collecting the accumulated learning from the entrepreneurs leading women-owned businesses, to help instruct “intrapreneurs” to follow their lead by claiming higher positions of authority in traditional organizations.

\section{Familial Responsibility}

\section{Barriers to Claiming Authority}

Many argue that the most obvious and difficult barrier to women achieving leadership positions is that they bear a disproportionate share of childrearing and household management responsibilities (Mahoney, 1996). Working moms tend feel they have primary responsibility for childcare and household duties and experience significantly more guilt than male partners over family-work conflicts. For example, in a study of 139 married couples with young children and 
relatively equal-status careers in business or academia, researchers observed "considerable, traditional inequity in the distribution of child-care tasks and chore responsibility” (Biernat \& Wortman, 1991, p. 844). In spite of carrying a disproportionate share of the at-home workload, the women in the study reported being generally satisfied with their husbands' contribution to the domestic labor and relatively critical of their own household performance (Biernat \& Wortman, 1991).

Role conflicts and time constraints created by simultaneous responsibilities at work and at home carry substantial implications for women's life choices and career trajectories. Some women cope by eliminating traditional roles, not marrying or choosing not to have children (Hall, 1972; Hewlett, 2002; Nieva \& Gutek, 1981). A 2001 survey found that, among "ultra high-achieving women” in corporate America (i.e., with annual earnings of $\$ 100,000$ or higher) 49 percent had no children by the age of 40 . This figure compares to 19 percent for "ultra-high achieving men” (i.e., with annual earnings of \$200,000 of higher) (Hewlett, 2002)—and to approximately 20 percent for the general population of American women age 40 (Bachu \& O'Connell, 2001). A 2001 study of Harvard Business School graduates from classes of 1981, 1986, and 1991 found that only 38 percent of the female graduates were working full time. The majority of the women from the HBS graduating classes had substantially or completely disengaged from the workforce to spend more time with their children and spouses (Blagg and Young, 2002).

One strategy that working mothers adopt is the "superwoman” approach (Nieva \& Gutek, 1981): “coping through reactive role behavior...whose aim is to meet all of the role demands experienced” (Hall, 1972, p. 479). For many woman, this is an impossible standard to which to hold themselves and one that the places the entire overload problem on women's shoulders 
(Nieva \& Gutek, 1981, p. 49). Beyond wearing women down, “double-duty” (Biernat \& Wortman, 1991; Hochschild, 1990) places constraints on women’s social lives. Without time to spare, "superwomen" have few opportunities to deepen and broaden their informal networks and thereby accumulate the social capital needed to leverage themselves into high-profile positions (Ibarra, 1992, 1993; Nieva \& Gutek, 1981; Wellington \& Giscombe, 2001).

An alternative to becoming "superwoman" is to cope with work-home role and time conflicts by reducing workforce attachment and choosing an intermittent or part-time work style. Women who choose this alternative tend to readjust their career aspirations (Hall, 1972; Nieva \& Gutek, 1981). When they reenter the workforce, it tends to be at lower-level positions than they departed from earlier in their careers (Nieva \& Gutek, 1981) and to be at lower levels of pay as compared to women who had continued working (Waldfogel, 1998). This is in part because reentry women find their training or skills to be outdated, but also because they have a diminished self-concept with regard to their workplace skills, abilities and leadership potential (Nieva \& Gutek, 1981; Padula, 1994).

\section{Opportunities}

A potentially more productive response to work-family barriers than reactive role management (e.g., playing superwoman) or personal role redefinition (e.g., choosing between home/family or career) is "structural role redefinition" (Hall, 1972, p. 477). Structural role redefinition involves engaging with family and work partners to renegotiate role-based expectations and resources (Hall, 1972, p. 477). At home, this means negotiating a workable distribution of household labor between spouses, partnering with friends and extended family, and hiring additional support to fill in where there are not the resources within the family to cover all responsibilities. 
Again the example of women entrepreneurs suggests numerous potential models for how to restructure workplaces to better enable women to pursue their ideals at home and at work. High-achieving self-employed women are significantly less likely to be childless than highachieving corporate women (22 percent v. 42 percent) (Hewlett, 2002). The percentage of women entrepreneurs with children (78 percent) is very close to the national average for all women of age 40 (80 percent) (Bachu \& O'Connell, 2001).

Even within larger organizations, there is increasing evidence that family-friendly institutional reforms can carry significant benefits for women’s workforce participation after childbirth. The study of organizations with and without job-protected maternity leave in the US and UK shows that women who had leave coverage and returned to work after childbirth received a wage premium that offset the commonly observed “family gap” favoring women without children (Waldfogel, 1998). By instituting work arrangements that take into account that work and family demands have to be managed in concert, organizations are more likely to retain working mothers on leadership tracks. With the benefit of higher levels of work experience, job tenure, and pay, we are likely to see more working mothers competing for top slots.

\section{Taking stock: Negotiating to Claim Authority}

Although there is certainly some validity to each of these four dominant explanations, none of them poses an insurmountable barrier to women claiming greater levels of authority. An analysis of each of the four explanations points to clearly negotiable opportunities for change. Although gender-based social roles and stereotypes are dense and constraining, they are not intractable. Norms, beliefs, and behavior are part of a negotiated order, and, as eloquently stated by Constance Buchanan, founding director of the Harvard Divinity School's Women’s Studies in Religion program: 
Women especially possess the will to take the initiative in this social reorganization....Pressed to rearrange the meaning and structure of their own lives, they can more easily notice and question the institutional and work norms to which most men have become habituated (Hartman, 1999, p. 19).

If it takes particular types of work experience and/or high-profile work opportunities to make it to the top, women can negotiate for those positions. If women want to be leaders, they can find ways to make their preferences known and to ask for others' support in achieving their aims. If the complexity of work and family life creates constraints, women can renegotiate their own and others' role expectations and claim the necessary resources and assistance.

But, if these opportunities to renegotiate gendered assumptions, work experiences, leadership opportunities, and role constraints are so clear, why haven’t women seized them already? We propose that recent developments in the study of gender in negotiation may shed light on the gender gap in the claiming of authority.

\section{Gender in Negotiation}

Recent developments in the study of gender in negotiation have shown that the effects of gender on negotiation outcomes are contingent on situational factors (Kray, Thompson, \& Galinsky, 2001; Bowles, McGinn, \& Babcock, 2003; Walters, Stuhlmacher, \& Meyer, 1998). More specifically, this research suggests that sex differences are more likely to emerge when there is ambiguity about the bargaining range and the appropriate standards for negotiated agreement, and when gender is relevant and salient to behavior or performance expectations (Bowles et al., 2003). We propose that insights from these recent developments in the study of gender in negotiation may help to illuminate why women are finding it so difficult to negotiate their way past the above-described barriers. 


\section{Moderators of Gender Effects in Negotiation: Ambiguity and Gender Triggers}

Ambiguity

Ambiguity about the bargaining range and the appropriate standards for agreement opens the door for gender-based norms and preconceptions to influence negotiation expectations and outcomes (Bowles, et al., 2003). We rely on past experience and preconceptions to fill in the blanks when there are no clear external standards to use to judge or interpret a situation. For instance, there is extensive evidence from field and laboratory studies that sex biases in performance evaluations and hiring decisions are positively associated with the amount of subjective inference required by the evaluator; the more job-relevant information that is available, the less likely it is that the worker's sex will inform the evaluator's judgment (Chang, 2000; Foddy \& Smithson, 1999; Heilman, 1995; Heilman, 1984; Heilman, Martell, \& Simon, 1988; Lenney, Mitchell, \& Browning, 1983; Pfeffer, 1977; Pheterson, Kiesler, \& Goldberg, 1971; Tosi \& Einbender, 1985). Ambiguity has also been shown to play a role in men and women's own expectations for themselves. Research on the entitlement effect, for instance, shows that women (as compared to men) will expect less pay for equal labor and work longer and with fewer errors for equal pay, but only in the absence of clear pay comparison information (Callahan-Levy \& Messe, 1979; Major, McFarlin, \& Gagnon, 1984). When comparison standards for compensation are made clear, there are no significant gender difference in what men and women believe they should be paid (Major \& Forcey, 1985). This effect is partially explained by evidence that, when compensation standards are unclear, men and women will tend to look to compare themselves to similar (viz., same-gender) others for information on how to compensate themselves. In a society where men tend to be granted more compensation and other material resources than women, it is reasonable for men and women anchor on different 
reference points when setting their compensation expectations in ambiguous situations (Crosby, 1982; Major \& Forcey, 1985).

\section{$\underline{\text { Gender Triggers }}$}

“Gender trigger” encapsulates the notion that there are circumstances in which gender becomes relevant and salient to behavior or performance expectations. Gender triggers reflect sex-based stereotypes and social roles that are embedded in our social fabric (Kolb and Williams, 2000). Because of this embeddedness, they do not need to be embraced or consciously considered in order to shape expectations or behavior (Eagly, 1987; Steele, 1997). Gender triggers influence negotiation by prescribing distinct behavioral scripts and outcome expectations for male and female negotiators (Bowles et al., 2003). Negotiation research has identified three examples of potential gender triggers in bargaining: competitive v. integrative negotiation, negotiating for the self v. others, and the activation of implicit stereotypes.

Competitive v. Integrative Negotiation. Competitive negotiations are consistent with the norms of appropriate masculine behavior (e.g., being agentic, self-promoting) and they contradict the norms of appropriate feminine behavior (e.g., maintaining a communal- as opposed to self-orientation) (Bakan, 1966). Integrative negotiations, in contrast, call for a mix of value creating and value claiming behavior (Lax \& Sebenius, 1986), which does not clearly contradict or conform to either gender stereotype. Because competitive bargaining is a relatively masculine domain, male negotiators are likely to have more confidence and higher performance expectations in competitive negotiations than are female negotiators (Beyer, 1990; Beyer \& Bowden, 1997; Lenney, 1981). Consistently, much of the evidence that gender has the potential to influence negotiation expectations and performance is based on studies of competitive negotiations, such as the ultimatum game (Solnick, 2001), sale price (Ayres, 1991; Kray et al., 
2001), and salary negotiations (Gerhart \& Rynes, 1991; Bowles et al., 2003; Stevens, Bavetta, \& Gist, 1993).

Negotiating for Self v. Other. Because the norms of appropriate feminine behavior prescribe that women behave in other-oriented as opposed self-interested ways, women are likely to be particularly inhibited by competitive negotiations for the self as opposed to for others (Kolb and Williams, 2000). One recent experimental study showed that women’s negotiating intentions were moderated by whether the negotiation concerned the negotiator's own wage or the wage to be received by an anonymous other. When negotiating for someone else, female negotiators reported that they would ask for $22 \%$ more on average than they would when they were negotiating for themselves. Negotiating for self or other had no influence on males’ negotiating intentions (Bowles et al., 2003).

Activation of Implicit Stereotypes. Motivated by Claude Steele’s work on stereotype threat, negotiation researchers have shown that the implicit priming of gender-based stereotypes can lead negotiators to fulfill stereotype-based expectations (Kray et al., 2001). For example, Steele and colleagues administered a math test to mathematically inclined young women and men. When the researchers' introduction to the exam mentioned that there tended to be gender differences in test performance, women performed significantly worse than men. When the researchers mentioned that the tests tended not to produce gender differences, there was no significant difference in performance by sex (Spencer, Steele, \& Quinn, 1999). Applied to negotiation, Kray and her colleagues showed that the threat of negative stereotype confirmation could undermine women's negotiating performance. Stating that negotiation outcomes are evaluative of "true” negotiating ability (v. non-evaluative), or presenting the negotiation task in 
gendered (v. neutral) language, negatively affected women's negotiating performance relative to men’s (Kray et al., 2001).

Recent developments in the research on gender in negotiation shed new light on the gender gap in leadership positions: the race to claim authority calls for just those types of negotiations in which gender differences tend to emerge. Negotiations to claim greater authority call for women to negotiate competitively for themselves in domains that are rife with negative gender-based stereotypes and where what exactly is up for negotiation can be highly ambiguous. The types of negotiations in which women need to more proactively engage in order to compete more effectively for leadership positions are precisely the types of negotiations that are likely to be relatively inhibiting or less effective for women.

\section{Conclusion}

Psychological researchers may gain new insights into the study of gender in leadership by building on recent developments in the study of gender in negotiation. It seems unlikely that the relatively small gender differences—sometimes favoring males, sometimes favoring females or neither-observed in leadership style and effectiveness can account for the relatively dramatic gender gap in leadership positions. In order to understand the gender gap in leadership, we propose that psychological researchers refocus their attention on the path to leadership positions and away from what men and women tend to do or how well they perform once they reach those positions.

This new research direction we propose is consistent with and complementary to the most recent developments in the psychological study of gender and leadership. Following more than a decade of research on gender and leadership, Alice Eagly has proposed the pursuit of new research on prejudice as a barrier to women’s advancement into leadership positions (Eagly \& 
Karau, 2002). Eagly and Karau propose that perceived incongruity between female gender roles and leadership roles leads women to be undervalued as potential leadership candidates. We embrace the notion that gender-based social roles and sex-stereotypes have the potential to color both prospective leaders' aspirations and observers’ judgments of leadership candidates. We propose to focus on the influence of these "gender triggers" in negotiations to claim authority, because we believe that negotiations over the resources and opportunities to gain positions of authority make up a particularly influential set of social interactions in determining who becomes a leader.

Recent developments in the study of gender in negotiation suggest that men and women are likely to have divergent perceptions entering negotiations to claim authority, and that these are precisely the types of negotiations in which the outcomes have historically favored males. The study of negotiations, therefore, carries the potential to generate useful prescriptive suggestions for individuals who aspire to leadership positions. Such micro-level prescriptions provide individuals with options for changing situations to their own advantage in the short term rather than waiting for macro-level developments, such as the reduction of prejudice and/or the feminization of leadership (Eagly \& Karau, 2002).

The study of negotiations to claim authority will benefit from further research in both the laboratory and the field. Laboratory researchers could test whether manipulation of ambiguity and "gender triggers" (e.g., perceived gender role incongruity) moderates gender differences in expectations and outcomes in negotiations over leadership-relevant resources (e.g., work opportunities, votes or funds for task completion). Field research could test when and how gender differences emerge in prospective leaders’ negotiation expectations over leadershiprelevant resources. Research within organizations could also explore gender differences in the 
frequency of negotiations over leadership-relevant resources and also whether men and women have qualitatively different information and/or opportunities for negotiations over leadership relevant resources. Finally, ethnographic work could explore inductively the work arrangements of women entrepreneurs to see if they suggest negotiable alternatives for enhancing the leadership potential of women in larger organizational settings.

The gender gap in leadership positions can be reduced through negotiation. Although women face legitimate barriers in their negotiations to claim authority, the playing field is ripe with opportunities for women to enhance their negotiating power and to reshape negotiating situations in their own favor-and ultimately to claim the authority they seek. 


\section{References}

Andrews, P. H. (1992). Sex and gender differences in group communication: Impact on the facilitation process. Small Group Research, 23(1), 74-94.

Ayres, I. (1991). Fair driving: Gender and race discrimination in retail car negotiations. Harvard Law Review, 104, 817.

Bachu, A., \& O'Connell, M. (2001). Fertility of American women: June 2000. Washington, DC: Economics and Statistics Administration, US Census Bureau, US Department of Commerce.

Bakan, D. (1966). The duality of human existence. Chicago: Rand McNally.

Beyer, S. (1990). Gender differences in the accuracy of self-evaluations of performance. Journal of Personality and Social Psychology, 59, 960-970.

Beyer, S., \& Bowden, E. M. (1997). Gender differences in self-perceptions: Convergent evidence from three measures of accuracy and bias. Personality and Social Psychology Bulletin, $\underline{23}, 157-172$.

Biernat, M., \& Wortman, C. B. (1991). Sharing of home responsibilities between professionally employed women and their husbands. Journal of Personality \& Social Psychology, 60(6), 844-860.

Branson, L. (2002, March 17). Reform of the bully broads. The Boston Globe Magazine, 12-17.

Bureau of Labor Statistics. (2002). Highlights of women's earnings in 2001 (960). Washington, D.C.: US Department of Labor.

Burns, J. M. (1978). Leadership. New York, NY: Harpertorch Books. 
Callahan-Levy, C., \& Messe, L. A. (1979). Sex differences in the allocation of pay. Journal of Personality and Social Psychology, 37(3), 433-446.

Catalyst. (1996). Catalyst--Working with business and the professions to effect change for women. New York: Catalyst.

Catalyst. (1998). Advancing women in business--the Catalyst guide best practices from the corporate leaders (1st ed.). San Francisco, Calif.: Jossey-Bass.

Catalyst. (2002, November 19, 2002). Catalyst census marks gains in numbers of women corporate officers in Amierca's largest 500 companies [website]. Retrieved January 23, 2003, from the World Wide Web:

Cejka, M. A., \& Eagly, A. H. (1999). Gender-stereotypic images of occupations correspond to the sex segregation of employment. Personality \& Social Psychology Bulletin, 25(4), 413-423.

Center for American Women and Politics. (2002). Women Who Will Serve in the 108th Congress 2003-05 [website]. Eagleton Institute of Politics, Rutgers, The State University of New Jersey. Retrieved January 23, 2003, from the World Wide Web:

http://www.cawp.rutgers.edu/facts/cong-03.html

Chang, P. M. Y. (2000). Discrimination by design: The effects of organizational design on the exercise of gender discrimination in denominational labor markets (working paper). Chesnut Hill, MA: Boston College.

Cohen, L. E., Broschak, J. P., \& Haveman, H. A. (1998). And then there were more? The effect of organizational sex composition on the hiring and promotion of managers. American Sociological Review, 63, 711-727. 
Crosby, F. (1982). Relative deprivation and working women. New York: Oxford University Press.

Diekman, A. B., \& Eagly, A. H. (2000). Stereotypes as dynamic constructs: Women and men of the past, present, and future. Personality \& Social Psychology Bulletin, 26(10), 1171.

Dovidio, J. F., Ellyson, S. L., Keating, C. F., \& Heltman, K. (1988). The relationship of social power to visual displays of dominance between men and women. Journal of Personality and Social Psychology, 54, 233-242.

Eagly, A. H. (1987). Sex difference in social behavior: A social-role interpretation. Hillsdale, NJ: Lawrence Erlbaum Associates, Publishers.

Eagly, A. H., \& Johannesen-Schmidt, M. C. (2001). The leadership styles of women and men. Journal of Social Issues, 57(4), 781-797.

Eagly, A. H., Johannesen-Schmidt, M. C., \& van Engen, M. L. (2002). Transformational, transactional and laissez-faire leadership styles: A meta-analysis comparing men and women (manuscript under review): Northwestern University.

Eagly, A. H., \& Johnson, B. T. (1990). Gender and leadership style: A meta-analysis. Psychological Bulletin, 108(2), 233-256.

Eagly, A. H., \& Karau, S. J. (1991). Gender and the emergence of leaders: A metaanalysis. Journal of Personality \& Social Psychology, 60(5), 685-710.

Eagly, A. H., \& Karau, S. J. (2002). Role congruity theory of prejudice toward female leaders. Psychological Review, 109(3), 573-598.

Eagly, A. H., Makhijani, M. G., \& Klonsky, B. G. (1992). Gender and the evaluation of leaders: A meta-analysis. Psychological Bulletin, 111(1), 3-22. 
Eagly, A. H., \& Steffen, V. J. (2000). Gender stereotypes stem from the distribution of women and men into social roles, Stangor, Charles (Ed). (2000). Stereotypes and prejudice: Essential readings. Key readings in social psychology. (pp. 142-160). Philadelphia, PA, US; Philadelphia, PA, US: Psychology Press/Taylor \& Francis; Psychology Press/Taylor \& Francis. Ely, R. J. (1994). The effects of organizational demographics and social identity on relationships among professional women. Administrative Science Quarterly, 39(2), 203-238.

Ely, R. J. (1995). The power of demography: Women's social constructions of gender identity at work. Academy of Management Journal, 38(3), 589-635.

Fletcher, J. K. (2001). Disappearing acts: Gender, power and relational practice at work. Boston: MIT Press.

Foddy, M., \& Smithson, M. (1999). Can gender inequalities be eliminated? Social Psychology Quarterly, 62(4), 307-324.

Gerhart, B., \& Rynes, S. (1991). Determinants and consequences of salary negotiations by male and female MBA graduates. Journal of Applied Psychology, 76(2), 256-262.

Hall, D. T. (1972). A model of coping with role conflict: The role behavior of college educated women. Administrative Science Quarterly, 17(4), 471-486.

Hartman, M. S. (1999). Talking leadership : conversations with powerful women. New Brunswick, N.J.: Rutgers University Press.

Heilman, M. (1995). Sex stereotypes and their effects in the workplace: What we know and what we don't know. Journal of Social Behavior and Personality, 10(6), 3-26.

Heilman, M. E. (1980). The impact of situational factors on personnel decisions concerning women: Varying the sex composition of the applicant pool. Organizational Behavior and Human Performance, 26(3), 286-295. 
Heilman, M. E. (1984). Information as a deterrent against sex discrimination: The effects of applicant sex and information type on preliminary employment decisions. Organizational Behavior and Human Performance, 33(2), 174-186.

Heilman, M. E., Martell, R. F., \& Simon, M. C. (1988). The vagaries of sex bias: Conditions regulating the undervaluation, equivaluation, and overvaluation of female job applicants. Organizational Behavior and Human Decision Processes, 41(1), 98-110.

Hewlett, S. A. (2002). Creating a life: Professional women and the quest for children. New York: Talk Miramax Books.

Hochschild, A. R. (1990). The second shift: Inside the two-job marriage. New York: Morrow/Avon.

Ibarra, H. (1992). Homophily and differential returns: Sex differences in network structure and access in an advertising firm. Administrative Science Quarterly, 37(3), 422-447.

Ibarra, H. (1993). Network centrality, power, and innovation involvement: Determinants of technical and administrative roles. Academy of Management Journal, 36(3), 471-500.

Kanter, R. (1977). Numbers: Minorities and majorities, In Men and women of the corporation (pp. 206-242).

Kanter, R. M. (1977). Some effects of proportions on group life: Skewed sex ratios and responses to token women. American Journal of Sociology, 82(5), 965-990.

Kolb, D. M. (1992). Women's work: Peacemaking in organizations. In D. M. Kolb \& J. M. Bartunek (Eds.), Hidden conflict in organizations: Uncovering behind-the-scenes disputes (pp. 63-91). Newbury Park, CA: Sage Publications. 
Kolb, D. M. and Williams, J. (2000). The Shadow Negotiation: How Women Can Master The Hidden Agendas That Determine Bargaining Success. New York: Simon and Schuster.

Kray, L. J., Thompson, L., \& Galinsky, A. (2001). Battle of the sexes: Gender stereotype confirmation and reactance in negotiations. Journal of Personality and Social Psychology, 80(6), 942-958.

Lax, D., \& Sebenius, J. (1986). The manager as negotiator: Bargaining for cooperation and competitive gain. New York: Free Press.

Lee, L.-E. (2001). Feeling well-paid: The effect of labor market structure and social comparisons on pay evaluation (Qualifying Paper submitted to Department of Sociology). Cambridge, MA: Harvard University.

Lenney, E. (1981). What's fine for the gander isn't always good for the goose: Sex differences in self-confidence as a function of ability area and comparison with others. $\underline{\text { Sex }}$ Roles, 7, 905-923.

Lenney, E., Mitchell, L., \& Browning, C. (1983). The effect of clear evaluation criteria on sex bias in judgments of performance. Psychology of Women Quarterly, 7(4), 313-328.

Lowe, K. B., Kroeck, K. G., \& Sivasubramaniam, N. (1996). Effectiveness correlates of transformational and transactional leadership: A meta-analytic review of the MLQ literature. Leadership Quarterly, 7, 385-425.

Major, B., \& Forcey, B. (1985). Social comparisons and pay evaluations: Preferences for same-sex and same-job wage comparisons. Journal of Experimental Social Psychology, 21(4), 393-405. 
Major, B., McFarlin, D. B., \& Gagnon, D. (1984). Overworked and underpaid: On the nature of gender differences in personal entitlement. Journal of Personality \& Social Psychology, 47, 1399-1412.

Neubert, M. J. (1999). Too much of a good thing or the more the merrier? Exploring the dispersion and gender composition of informal leadership in manufacturing teams. Small Group Research, 30(5), 635-646.

Nieva, V. F., \& Gutek, B. A. (1981). Women and work: A psychological perspective. New York: Praeger Publishers.

Padula, M. A. (1994). Reentry women: A literature review with recommendations for counseling and research. Journal of Counseling and Development, 73(1), 10-16.

Pfeffer, J. (1977). Toward an examination of stratification in organizations. Administrative Science Quarterly, 22(4), 553-567.

Pheterson, G. I., Kiesler, S., \& Goldberg, P. A. (1971). Evaluation of the performance of women as a function of their sex, achievement, and personal history. Journal of Personality and Social Psychology, 19, 114-118.

Ridgeway, C. L. (2001). Gender, status and leadership. Journal of Social Issues, 57(4), 637-655.

Ridgeway, C. L., \& Smith-Lovin, L. (1999). Gender and interaction. In J. S. Chafetz (Ed.), Handbook of the Sociology of Gender (pp. 247-274). New York: Kluwer Academic / Plenem Publishers.

Bowles, H. R., McGinn, K. L., \& Babcock, L. (2003). When does gender matter in negotiation? (Working Paper). Cambridge, MA: Kennedy School of Government, Harvard University. 
Rosener, J. B. (1990). Ways women lead. Harvard Business Review(NovemberDecember), 119-126.

Rudman, L. A. (1998). Self-promotion as a risk factor for women: The costs and benefits of counterstereotypical impression management. Journal of Personality and Social Psychology, 74(3), 629-645.

Rudman, L. A., \& Glick, P. (1999). Feminized management and backlash toward agentic women: The hidden costs to women of a kinder, gentler image of middle managers. Journal of Personality \& Social Psychology, 77(5), 1004-1010.

Schein, V. E. (2001). A global look at psychological barriers to women's progress in management. Journal of Social Issues, 57(4), 675-688.

Sharpe, R. (2000, November 20). As leaders, women rule. Business Week, 74.

Small Business Administration, U. G. (2001, August 10, 2001). Startling new statistics [website]. SBA Online Women's Business Center. Retrieved December 6, 2002, from the World Wide Web: http://www.onlinewbc.gov/docs/starting/new_stats.html

Solnick, S. J. (2001). Gender differences in the ultimatum game. Economic Inquiry, $\underline{39}(2), 189-200$.

Spencer, S. J., Steele, C. M., \& Quinn, D. M. (1999). Stereotype threat and women's math performance. Journal of Experimental Social Psychology, 35(1), 4-28.

Steele, C. M. (1997). A threat in the air: How stereotypes shape intellectual ability and performance. American Psychologist, 52, 613-629.

Stevens, C. K., Bavetta, A. G., \& Gist, M. E. (1993). Gender differences in the acquisition of salary negotiation skills: The role of goals, self-efficacy, and perceived control. Journal of Applied Psychology, 78(5), 723-735. 
Tosi, H. L., \& Einbender, S. W. (1985). The effects of the type and amount of information in sex discrimination research: A meta-analysis. Academy of Management Journal, $\underline{28}(3), 712-723$.

Valian, V. (1999). Why so slow? The advancement of women. Cambridge, MA: The MIT Press.

Waldfogel, J. (1998). The family gap for young women in the United States and Britain: Can maternity leave make a difference? Journal of Labor Economics, 16(3), 505-545.

Walters, A. E., Stuhlmacher, A. F., \& Meyer, L. L. (1998). Gender and negotiator competitiveness: A meta-analysis. Organizational Behavior and Human Decision Processes, $\underline{76}(1), 1-29$.

Wellington, S., \& Giscombe, K. (2001). Women and leadership in corporate America. In C. B. Costello \& A. J. Stone (Eds.), The American woman 2001-2002: Getting to the top. New York: W. W. Norton \& Company.

Wirth, L. (2001). Breaking through the glass ceiling: Women in management. Geneva, Switzerland: International Labour Office.

Wood, W., \& Eagly, A. H. (2002). A cross-cultural analysis of the behavior of women and men: Implications for the origins of sex differences. Psychological Bulletin, 128(5), 699727.

Wood, W., \& Karten, S. J. (1986). Sex differences in interaction style as a product of perceived sex differences in competence. Journal of Personality \& Social Psychology, 50(2), 341-347. 
Woodall, J., Edwards, C., \& Welchman, R. (1995). Winning the lottery? Organizational restructuring and women's managerial career development. Women in Management Review, 10(3), 32-39. 